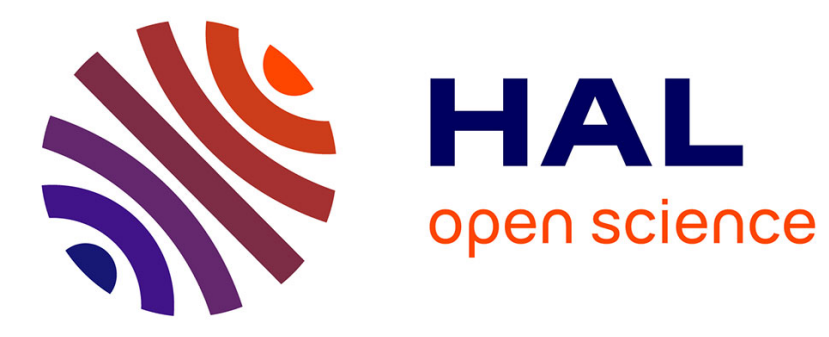

\title{
Prevalence of hematozoan parasites in Red Kite nestlings from France
}

Michael Coeurdassier, Nicolas Bassin, Thibaut Powolny, Christophe Morin, Eve Afonso

\section{- To cite this version:}

Michael Coeurdassier, Nicolas Bassin, Thibaut Powolny, Christophe Morin, Eve Afonso. Prevalence of hematozoan parasites in Red Kite nestlings from France. Wilson journal of ornithology, 2021, 162 (2), pp.521-527. 10.1007/s10336-020-01838-w . hal-03278548

\section{HAL Id: hal-03278548 https://hal.science/hal-03278548}

Submitted on 5 Jan 2022

HAL is a multi-disciplinary open access archive for the deposit and dissemination of scientific research documents, whether they are published or not. The documents may come from teaching and research institutions in France or abroad, or from public or private research centers.
L'archive ouverte pluridisciplinaire HAL, est destinée au dépôt et à la diffusion de documents scientifiques de niveau recherche, publiés ou non, émanant des établissements d'enseignement et de recherche français ou étrangers, des laboratoires publics ou privés. 
1 Michael Coeurdassier ${ }^{1}$. Nicolas Bassin ${ }^{1}$. Thibaut Powolny ${ }^{1}$. Christophe Morin²,3.

$2 \quad$ Eve Afonso ${ }^{1}$

3

$4 \quad$ Prevalence of hematozoan parasites in Red Kite nestlings

5 from France

6

$7{ }^{1}$ Department Chrono-environment - University of Franche-Comté, UMR/CNRS

86249,16 route de Gray, 25030 Besançon, France

$9 \quad{ }^{2}$ LPO Franche-Comté, 7 rue Voirin, 25000 Besançon, France

370120 Confracourt, France

Author for correspondence: Michael Coeurdassier michael.coeurdassier@univ$\underline{\text { fcomte.fr }}$

ORCID identifiers: Michael COEURDASSIER: https://orcid.org/0000-0002-6260311X / Nicolas BASSIN: no ORCID Id / Thibaut POWOLNY: https://orcid.org/00000001-6580-9853 / Christophe MORIN: no ORCID Id / Eve AFONSO: 


\section{Abstract}

Blood pathogens may be harmful for birds and thus, represent a potential threat for some populations. To date, only few data are available on the prevalence of hematozoans in the Red Kite, a raptor endemic to the Western Palearctic listed as Near Threatened within its global range. Here, we report the first screening of haemosporidian parasites in Red Kite nestlings from French breeding areas. The blood of 47 nestlings was sampled in three areas in Eastern France and the prevalence of three genera of blood pathogens, Leucocytozoon, Haemoproteus and Plasmodium, was measured based on PCR-assays. Thirteen nestlings were positive to Leucocytozoon sp. $(\mathrm{n}=13)$ and Plasmodium relictum $(\mathrm{n}=1)$, which corresponds to an overall prevalence of $28 \%$. This prevalence is higher than those previously reported for the Red Kite in other countries. This is the first record of $P$. relictum, a potential pathogen for birds, in the Red Kite. No relationship was found between the body condition of nestlings and the occurrence of haemosporidians. Our findings suggest that hematozoans could be a limited threat for nestlings but prevalence in adults, a sensitive stage for the population dynamic of Red Kite, remains poorly known and should be further investigated at least in its main breeding areas.

Key words: Haemosporida, Haemoproteus, Leucocytozoon, Plasmodium, raptor 


\section{Declarations}

Funding: This study was financially supported by the French Ministère de l'Ecologie et du Développement Durable (Plan National d'Actions pour la conservation du Milan Royal), by the Région Franche-Comté (BIOSCOPE project, convention 20160059) and by the Long Term Ecological Research (LTER) site Zone Atelier Arc Jurassien.

Conflicts of interest/Competing interests: The authors declare that they have no interest or competing conflicts

Ethical approval: All the manipulations were performed with authorizations no. 2015093-0007 and 2015093-0023 in the framework of the Red Kite national conservation plan.

All the authors consent to participate and for publication

Availability of data and material: The data presented in this article are referenced in the metadata platform dat@OSU proposed by the Observatoire des Sciences de I'Univers Terre Homme Environnement Temps Astronomie (OSU THETA)

Code availability: NA

Authors' contributions: Michael Coeurdassier designed the study. Christophe Morin and Michael Coeurdassier managed and carried out fieldwork and sampling. Eve Afonso and Nicolas Bassin conducted the pathogen analysis. Michael Coeurdassier, Eve Afonso, Thibaut Powolny and Nicolas Bassin analyzed and interpreted the data and wrote the manuscript. All co-authors commented on the manuscript and accepted the final version. 
61

62

63

64

65

66

67

68

69

70

71

72

\section{Aknowledgements}

We are grateful to Damien Bertin, Violaine Champion, Natacha Leclerc, Geneviève Magnon, Dominique Michelat, Jacques Morel, François Rey-Demaneuf, François Richard, Michel Sauret, Bruno Tissot and all the volunteers for ensuring the monitoring of the studied Red Kite populations. We warmly thank the three anonymous referees for their contribution to improve this article. This study was

7 financially supported by the French Ministère de l'Ecologie et du Développement

8 Durable (Plan National d'Actions pour la conservation du Milan Royal), by the 69 Région Franche-Comté (BIOSCOPE project, convention 2016-0059) and by the 70 LTER site Zone Atelier Arc Jurassien. The molecular analyses were carried out on 1 the PEA2t platform. The experiments comply with the current laws of France when 2 they were performed. 


\section{Introduction}

The Red Kite Milvus milvus is an Accipitridae endemic to the Western Palearctic. It breeds mainly in Germany, France and Spain, which together hold around $75 \%$ of the global population (Knott et al. 2010). In these countries, the populations have been estimated to be declining, which led the International Union for the Conservation of Nature to assess the Red Kite as Near threatened (BirdLife International 2020) within its global range while it is currently listed as vulnerable in France (UICN France et al. 2016). The main threats identified are poisoning by anticholinesterasic pesticides and rodenticides, decrease of livestock, homogenization of landscapes and potentially wind turbines (BirdLife International 2020). In both Europe and France, the decline reported during the period 1990-2010 has led to the implementation of a Conservation Plan in which the health status of the Red Kite was surveyed, notably on nestlings that were caught at nests for ringing and wing-marking. Among the health indicators monitored and considering that ecotoxicological issues were identified, chemical concentrations in blood were measured and we showed that $50 \%$ of nestlings were exposed to organic compounds and/or metals (Coeurdassier et al. 2014; Powolny et al. 2020). If infection by pathogens has not been pointed out as a threat for the Red Kite, only few studies have focused on the prevalence of blood parasites and no data are available on the prevalence of hematozoan pathogens in Red Kite nestlings from France. Haemosporidians belonging to three genera of protozoan (Haemoproteus, Leucocytozoon, and Plasmodium) are intracellular blood parasites transmitted to hosts by bloodsucking dipteran vectors, they have been commonly detected in birds including raptors (Remple 2004). Haemoproteus and Leucocytozoon are often considered to have little or no pathogenic effects on birds but their presence in some raptor nestlings has been related to subclinical effects and even host death. Plasmodium, the causative agent of malaria in animals, can be a serious avian 
pathogen, Plasmodium relictum being the species most commonly associated with virulent disease (Remple 2004). In raptors, haemosporidians may also negatively affect health such as body condition and life traits (Korpimaki et al. 1993; Hatchwell et al. 2001; Sol et al. 2003; Garvin et al. 2006). Here, we aim to measure the prevalence of common blood parasites in birds of the genera Haemoproteus, Leucocytozoon and Plasmodium in nestlings of three areas monitored in Eastern France. The relationship between prevalence and body condition of the nestlings was also checked to document whether such infection could affect individuals.

\section{Methods}

\section{Study areas and sample collection}

Fieldwork was carried out in 2015 from $4^{\text {th }}$ to $25^{\text {th }}$ June in Franche-Comté region, Eastern France. Three breeding populations of Red Kite, from three areas (called “Area” factor hereafter) were monitored: Sundgau Belfortain (47³80170’N, 6510460'E), Drugeon-Remoray basin (46540220'N, 6²10170'E) and Besançon plateau (47¹40350'N, 6010190'E). Forty-seven chicks (23 males and 24 females) corresponding to 24 nests (called "Nest" factor hereafter) were retained for the study. The sampling was implemented 15 days prior to the expected fledging date, when the chicks were approximately $25-40$ days old. Nestlings were removed from the nests by an experienced arborist climber and carried to the ground for data collection. First, the body mass (g) and the wing length (i.e., length from the extremity of the longest primary feather to the wrist of the right wing in $\mathrm{mm}$ ) were measured. Blood $(2 \mathrm{~mL}$ ) was sampled by trained operators from the brachial vein using lithium-heparin coated syringes. As recommended (Fair et al. 2010), the volume of blood collected was $<0.5 \%$ of the chick's body mass. Blood samples were kept in the dark at $4^{\circ} \mathrm{C}$ and then stored at $-20^{\circ} \mathrm{C}$ until processed in the laboratory. The sex of the chicks was determined according to a PCR method (Griffiths et al. 

1998) as described in Powolny et al. (2020). All the manipulations were performed with governmental authorizations no. 2015093-0007 and 2015093-0023 in the framework of the Red Kite national conservation plan.

\section{Body condition estimate}

In the present study, we define body condition as a proxy of energy reserves, mainly fat mass that represents a broad indicator of the health status of nestlings. According to Labocha and Hayes (2012), body mass of birds is « as good or nearly as good an indicator of fat content, as any of the other condition indices ». Because body mass can be easily and reliably measured, we used it as an estimate of body condition. As we studied growing individuals, difference in body mass could be due to slight differences in specimen age rather than in fat reserve. Mougeot and Bretagnolle (2006) showed that the wing length was closely correlated to the age of Red Kite nestlings. Moreover, the relationship they established is almost linear within the range of ages of the kite chicks we studied, thus, we used the wing length as an estimate of chick age. Body condition was calculated as the residuals of the linear model [body mass (in g) wing length (in $\mathrm{mm}$ )], which corresponds to an assessment of the body mass following a statistical elimination (sensus Grafen and Hails 2002) of age differences. Positive residuals were related to chicks in relative good condition while negative residuals represented kites in poor condition.

\section{DNA extraction, PCR amplification, sequencing, and parasite detection}

$$
\text { DNA was extracted from blood samples using the DNeasy Blood \& Tissue kit }
$$
(Qiagen, France) and according to manufacturer's instructions (protocol "Purification of Total DNA from Animal Blood or Cells"). A nested PCR was conducted to amplify a fragment of cytochrome b gene (542 bp) from species of Plasmodium, Haemoproteus and Leucocytozoon as recommended by Pérez-Rodríguez et al. (2013). A first PCR was performed in total volumes of $12.5 \mu \mathrm{L}$ including $1 \times$ Accustart 
II PCR ToughMix (Quanta Biosciences, USA), $0.6 \mathrm{mM}$ of each primer (Plas1F/HaemNR3), and 22 ng of total genomic DNA. The PCR program consisted in an activation step of $3 \mathrm{~min}$ at $94^{\circ} \mathrm{C}$, followed by 20 cycles of $30 \mathrm{sec}$ at $94^{\circ} \mathrm{C}, 20$ $\sec$ at $52^{\circ} \mathrm{C}, 30 \mathrm{sec}$ at $72^{\circ} \mathrm{C}$, and a final elongation of $5 \mathrm{~min}$ at $72^{\circ} \mathrm{C}$. We then used PCR products from the first PCR to conduct the following reaction in a total volume of $25 \mu \mathrm{L}$ comprising $1 \times$ Accustart II PCR ToughMix, $0.6 \mathrm{mM}$ of each primer (3760F/HaemJR4) and 2.5 $\mu \mathrm{L}$ of PCR products from the first PCR. The PCR program consisted in an activation step of 3 minutes at $94^{\circ} \mathrm{C}$, followed by 35 cycles of $30 \mathrm{sec}$ at $94^{\circ} \mathrm{C}, 20 \mathrm{sec}$ at $52^{\circ} \mathrm{C}, 30 \mathrm{sec}$ at $70^{\circ} \mathrm{C}$, and a final elongation of $5 \mathrm{~min}$ at $70^{\circ} \mathrm{C}$. PCR products were then separated and visualized using a Qiaxcel device (Qiagen, France) and a DNA High Resolution kit (Qiagen). A negative control (PCR grade water instead of DNA extract) was introduced every ten samples. PCR products which yielded an approximately $590 \mathrm{bp}$ fragment (including primers) were confirmed by sequencing. The amplified products were purified using the QIAquick PCR Purification Kit (Qiagen) according to manufacturer's instructions. Direct sequencing of the purified PCR products was performed with an automated sequencer (Applied Biosystems 3130 Genetic Analyzer) using the primers employed for the second PCR reactions. For each PCR-positive sample, we aligned forward and reverse DNA sequences to obtain a consensus of 479 bp (Pérez-Rodríguez et al. 2013). A homology search of the sequences generated in this study was then performed by conducting an online search with the NCBI Basic Local Alignment Search Tool for nucleotides (BLASTN) in the GenBank database (http://blast.ncbi.nlm.nih.gov/Blast.cgi).

Mixed infections were checked by examining electropherograms using the software BioEdit following the recommendations of Pérez-Tris and Bensch (2005). When double peaks were observed, we compared double peak patterns with the DNA sequences of parasite haplotypes already available on Genbank to identify which 
parasite haplotypes were involved in mixed infections (Pérez-Rodríguez et al.,

$1812013)$.

\section{Data analysis}

Difference of infection status (i.e., presence/absence of hematozoans) between sex was checked with a binomial generalized linear mixed effect model (GLMER) with 'Sex' as fixed factors and 'Nest' nested into 'Area' (Area/Nest) as random effects [corresponding full model: Status $\sim$ Sex $+(1 \mid$ Area/Nest $)]$. The relationship between the presence of at least one positive chick in the brood ('Positive brood', binomial variable) and the brood size was tested with a binomial generalized linear mixed effect model (GLMER) with 'Brood size' as fixed factors and 'Area' as random effects [corresponding full model: Positive brood Brood size + (1|Area)]. Relationship between body condition and infection status of the individual was checked with a linear mixed effect model (LMER) with 'Wing length', 'Sex' (in interaction or not with 'Wing length') and 'Status' as fixed factors and 'Nest' nested into 'Area' (Area/Nest) as random effects [corresponding full model: Body mass Wing length + Sex + Status $+(1 \mid$ Area/Nest) $]($ Zuur et al., 2009). The null model was also tested and the most parsimonious model with the lowest Akaike information criterion (AICc) was selected, a difference of $\mathrm{AICc}>2$ was retained to evidence difference between 2 models (Burnham and Anderson, 2010). Normality of model residuals and variance homoscedasticity were verified. All statistical analyses were performed using R 3.4.2. with the packages Ime4, pgirmess and ImerTest.

\section{Results}

Among the 47 chicks studied, 30 came from the Drugeon-Remoray basin (15 females and 15 males), 14 from the Besançon plateau (eight females and six males) and three from the Sundgau belfortain (one female and two males). Haemosporidian 
parasites were found in 13 chicks (i.e., 28\%), Leucocytozoon was detected in eight males and five females from the three studied areas and Plasmodium in a single male also infected by Leucocytozoon of the Sundgau belfortain population (Fig. 1). No difference of Leucocytozoon prevalence was evidenced between sex (binomial GLMER, $p=0.33$ ) or between brood size (binomial GLMER, $p=0.66$ ). We found two Leucocytozoon haplotypes, which perfectly matched (i.e. with a $100 \%$ identity on 479bp) with L-MILVUS1 (Genbank accession number JN164716) and LMILANS4 (JN164713) haplotypes described in Pérez-Rodríguez et al. (2013). The DNA sequence corresponding to L-MILVUS1 also closely matched with Leucocytozoon toddi (GenBank accession number DQ177272) with a 99\% identity. The DNA sequence amplified in the only sample positive for Plasmodium matched with Plasmodium relictum (GenBank accession number LN835311) with a 100\% identity over 462bp. Although Leucocytozoon toddi is a typical parasite of birds (Valkiūnas et al. 2010), we cannot exclude that we detected an unreferenced species genetically close, we thus retained Leucocytozoon ssp. hereafter, while we considered that DNA from Plasmodium relictum was detected in the corresponding positive nestling. The only PCR-positive sample for Plasmodium relictum was also positive for Leucocytozoon sp. (L-MILVUS1 haplotype) and we recorded three other individuals with a co-occurrence of both Leucocytozoon haplotypes L-MILVUS1 and L-MILANS4, among which two nestlings from the same brood. This suggests that co-infections can occur relatively frequently, both for interspecific (1/47 individual) and inter-haplotypes (3/47) co-occurrences.

At a same wing length, females are heavier than males (best LMER selected with 'Sex' as factor, $\mathrm{p}<0.0001$, Table 1. Estimate for males $=-84.8, \mathrm{df}=31.1, \mathrm{t}=-5.45$ ). Thus, the body condition of the nestlings is presented for both sex separately in Fig. 1. No difference of body condition was detected between infected and non-infected kites whatever the $\operatorname{sex}(p=0.15$, Table 1$)$. 


\section{Discussion}

235 Our findings showed that nestlings of Red Kite are infected by haemosporidians, notably Leucocytozoon ssp. and $P$. relictum, in three French breeding areas. The prevalence of $28 \%$ we measured was higher than those commonly reported for Leucocytozoon in Red Kite chicks from German, Spanish, UK or Danish populations while Plasmodium was less frequently found (Table 2). Overall, if we aggregate all the studies reported in Table 2 except our and without distinction of age, the prevalences measured in the Red Kite $(n=366)$ were $3.8 \%, 0.3 \%$ and $0.0 \%$ for Leucocytozoon, Haemoproteus and Plasmodium, respectively. Co-infection by two haplotypes of Leucocytozoon corresponding to some of those previously described in Spanish populations of Red Kite (Pérez-Rodriguez et al. 2013) were found in three nestlings of the French populations studied. We also point out that the detection of $P$. relictum in one single nestling of a French population is the first record for the Red Kite while several haplotypes of Plasmodium were detected in the Black Kite Milvus migrans (Pérez-Rodríguez et al. 2013; Nourani et al. 2020). More generally, $P$. relictum has alrealdy been reported in species belonging to Accipitridae and Falconidae families (Bennett et al. 1993). It is considered as a serious pathogen for birds and has been associated to virulent diseases and even death for translocated Gyrfalcon Falco rusticolus (Remple 2004). However, to our knowledge, no information is available on its harmfulness for Accipitridae and the individual infected by $P$. relictum we found did not show obvious health troubles. $50 \%$ or more notably in adults (e.g., Forrester et al. 1994; Castellucci et al. 1998), the genera Haemoproteus and Leucocytozoon being the most frequently detected while Plasmodium commonly has lower prevalence (Remple 2004). Overall, 
nestlings have been reported to exhibit relatively low prevalence of Haemosporida in numerous studies (e.g., Gutiérrez-López et al. 2015; Hanel et al. 2016) even if notable exceptions exist (Toyne and Ashford, 1997, Jeffries et al. 2015). Such differences of prevalences between juveniles and adults have been explained by the higher probability of adults contracting an infection in successive year (Podmokła et al. 2014). For the Red Kite, available data does not allow to identify a difference of prevalence between adults and nestlings mainly because of the low number of positive individuals and unbalanced samples (Table 2).

The comparison of Haemosporida prevalence of Red Kite in Spain to those determined in other studies (Table 2) suggests that it could be higher in more northern areas such as France and potentially in Denmark, UK and Western Europe despite low sample sizes. The prevalence of haemosporidians in diurnal raptors has been explained by different factors. Some are related to populations such as the abundance of Diptera vectors within the environment (Sol et al. 2003, Sehgal 2015) while others rely more on species features, such as the world geographic range, breeding habitat and embryonic development (Tella et al. 1999). In the case of the Red Kite, abundance of vectors has never been investigated directly in the previous studies published but it was assumed that the low prevalence measured in Spain could be due to the dryness of the environment, making it unsuitable for the main vectors of haemosporidian parasites (Tella et al. 1999). In Franche-Comté, the climate is more wet (annual rainfall from 1000 to $1500 \mathrm{~mm}$ against $600 \mathrm{~mm}$ in Spain) and numerous ponds, lakes and streams composed the landscape of the studied areas, which could at least partly explain the relatively high prevalence of Leucocytozoon. Moreover, the world range of the Red Kite limited to Western Europe, the absence of inter-continental migration notably through Africa and the fact that it breeds in open-woodland habitat are all together factors that may explain 
relatively low Haemosporida prevalence in raptors and more generally animals (Tella et al. 1999; Altizer et al. 2011). Lower body condition has been related to infection status (i.e., infected or not) by haemosporidians in both passerines (Garvin et al. 2006, Hatchwell et al. 2000) and raptors (Dawson and Bortolotti 2000). We did not show any effect of infection of Red Kite by Leucocytozoon on body condition, which suggests that these blood parasites might have no or weak pathogenic consequences on nestlings and/or that the infection intensity is too low to impair condition. In the American kestrel Falco sparverius, Dawson and Bortolotti (2000) found that a reduced condition of males was associated with higher intensity of infections by Haemoproteus using blood smear as a diagnostic tool. Moreover, Schoenle et al. (2017) reported that measuring intensity infection rather than only presence/absence could be important when evaluating the role of infection in influencing hosts' behaviour, physiology or fitness. If the molecular methods we used are considered as relevant to diagnose infection status of Red Kite by blood parasites (Martinsen et al. 2006, Krone et al. 2008), blood smears remain useful to measure the infection intensity in individuals and should be implemented complementarily to PCR screening in further studies.

Overall, both the low to medium prevalences reported in the different European populations studied and the absence of negative correlation with body condition we show suggest that hematozoans in Red Kite nestlings could be a limited threat for this life stage even if the detection of $P$. relictum in one chick questions about its occurrence at a larger scale and possible health effects on some individuals. In addition, recent findings showed that low-level chronic malaria infection reduced life span as well as the lifetime number and quality of offspring in a wild population of great reed warblers Acrocephalus arundinaceus, these delayed fitness effects of malaria being mediated by telomere degradation (Asghar et al. 2015). This stresses the need for further research on "subtle" hematozoan effect on individual in different 

avian groups including raptors. Moreover, the prevalence in adults has been only assessed in Spain, a country where it is particularly low, while breeder's survival is a critical parameter in the dynamic of raptor populations (Saether and Bakke 2000). Further investigation associating both qualitative and quantitative methods on a significant number of Red Kites and including adults, from other European areas, notably in Germany and France, would be needed to confirm whether blood pathogens can be considered as negligible threat for the Red Kite population.

\section{References}

Altizer S, Bartel R, Han BA (2011) Animal migration and infectious disease risk. Science 331: 296-302

Asghar M, Hasselquist D, Hansson B, Zehtindjiev P, Westerdahl H, Bensch S (2015) Hidden costs of infection: Chronic malaria accelerates telomere degradation and senescence in wild birds. Science 347: 436-438

Bennett GF, Peirce MA, Ashford RW (1993) Avian haematozoa: mortality and pathogenicity. J Nat Hist 27: 993-1001

BirdLife International (2020) Species factsheet: Milvus milvus. http://www.birdlife.org. Accessed 03 March 2020

Burnham KP, Anderson DR (2010) Model selection and multimodel inference: a practical information-theoretic approach. 2nd edn. Springer Press, New York

Castellucci SA, Oplinger SB, Klucsarits JR (1998) Hematology and detection of hemoparasites in the American Kestrel (Falco sparverius) during summer nesting period. J Pa Acad Sci 72: 29-31 
335 Coeurdassier M, Crini N, Amiot C, Fourel I, Berny P, Brand J, Scheifler R, Fritsch C,

336 Faggio G, Mionnet A, Morin C, Riols R (2014) Exposure of nestlings Red Kite to

337 rodenticides, PAHs and metals. 24th SETAC Europe Meeting, Basel

338 Dawson RD, Bortolotti GR (2000) Effects of hematozoan parasites on condition and 339 return rates of American kestrels. Auk 117: 373-380

340 Fair J, Paul E, Jones J (2010) Guidelines to the use of wild birds in research. Retrieved 341 from http://sccp.ca/sites/default/files/species-

342 habitat/documents/Guidelines\%20to\%20the\%20use\%20of\%20wild\%20birds\%20in\%20r

343 esearchornithological\%20council_August2010.pdf

344 Forrester DJ, Telford SR, Foster GW, Bennett GF (1994) Blood parasites of raptors in $345 \quad$ Florida. J Raptor Res 28: 226-231

346 Garvin MC, Szell CC, Moore FR (2006) Blood parasites of nearctic-neotropical migrant

347 passerine birds during spring trans-gulf migration: impact on host body condition. $\mathrm{J}$ $348 \quad$ Parasitol 92: 990-996

349 Grafen A, Hails R (2002) Modern statistics for the life sciences. Oxford University $350 \quad$ Press, Oxford

351 Griffiths R, Double MC, Orr K, Dawson RJ (1998) A DNA test to sex most birds. Mol 352 Ecol 7: 1071-1075

353 Gutiérrez-López R, Gangoso L, Martínez-de la Puente J, Fric J, López-López P, 354 Mailleux M, Muñoz J, Touati L, Samraoui B, Figuerola J (2015) Low prevalence of 355 blood parasites in a long-distance migratory raptor: the importance of host habitat. 356 Parasite Vector 8: 189. https://doi.org/10.1186/s13071-015-0802-9.

357 Hanel J, Doležalová J, Stehlíková Š, Modrý D, Chudoba J, Synek P, Votýpka J (2016)

358 Blood parasites in Northern Goshawk (Accipiter gentilis) with an emphasis to 359 Leucocytozoon toddi. Parasitol Res 115: 263-270 
Hatchwell BJ, Wood MJ, Anwar MA, Chamberlain DE, Perrins CM (2001) The haematozoan parasites of common blackbirds Turdus merula: associations with host condition. Ibis 143: 420-426

Jeffries MI, Miller RA, Laskowski MD, Carlisle JD (2015) High prevalence of Leucocytozoon parasites in nestling Northern Goshawks (Accipiter gentilis) in the Northern Great Basin, U.S.A. J Raptor Res 49: 294-302

Korpimaki E, Hakkarainen H, Bennett GF (1993) Blood parasites and reproductive success of Tengmalm's Owls: detrimental effects on females but not on males? Funct Ecol 7: 420-424.

Krone O, Priemer J, Streich J, Sommer P, Langgemach T, Lessow O (2001) Haemosporida of birds of prey and owls from Germany. Acta Protozool 40: 281-290

Krone O, Waldenström J, Valkiūnas G, Lessow O, Müller K, lezhova TA, Fickel J, Bensch S (2008) Haemosporidian blood parasites in European birds of prey and owls. J Parasitol 94: 709-715

Labocha MK, Hayes JP (2012) Morphometric indices of body condition in birds: a review. J Ornithol 153: 1-22

Laursen IM (2008) Environmental contamination, blood parasites, and home range of the Red Kite (Milvus milvus) in Denmark. Master of Science Disssertation, University of Copenhagen

Martinsen ES, Paperna I, Schall JJ (2006) Morphological versus molecular identification of avian Haemosporida: An exploration of three species concepts. Parasitology 133: 279_ 288

Mougeot F, Bretagnolle V (2006) Breeding biology of the Red Kite Milvus milvus in Corsica. Ibis 148: 436-448 
384 Nourani L, Zakeri S, Djadid ND (2020) Dynamics of prevalence and distribution pattern 385 of avian Plasmodium species and its vectors in diverse zoogeographical areas - A 386 review. Infect Genet Evol 104244. https://doi.org/10.1016/j.meegid.2020.104244

387

388

389

390

391

392

Peirce MA (1981) Distribution and host-parasite check-list of the Haematozoa of birds in Western Europe. J Nat Hist 15: 419-458

Peirce MA, Greenwood AG, Cooper JE (1983) Haematozoa of raptors and other birds from Britain, Spain and the United Arab emirates. Avian Pathol 12: 443-446

Pérez-Rodríguez A, de la Puente J, Onrubia A, Pérez-Tris J (2013) Molecular characterization of haemosporidian parasites from kites of the genus Milvus (Aves: Accipitridae). Int J Parasitol 43: 381-387

Perez-Tris J, Bensch S (2005). Diagnosing genetically diverse avian malarial infections using mixed-sequence analysis and TA-cloning. Parasitology 131: 15-23

Podmokła E, Dubiec A, Drobniak SM, Arct A, Gustafsson L, Cichoń M (2014) Determinants of prevalence and intensity of infection with malaria parasites in the Blue Tit. J Ornithol 155: 721-727

Poulin R (1996) Helminth growth in vertebrate hosts: Does host sex matter? Int J Parasitol 26: 1311-1315

Powolny T, Bassin N, Crini N, Fourel I, Morin C, Pottinger TG, Massemin S, Zahn S, Coeurdassier M (2020) Corticosterone mediates telomere length in raptor chicks exposed to chemical mixture. Sci Total Environ 706: 135083

Remple JD (2004) Intracellular Hematozoa of raptors: a review and update. J Avian Med Surg 18: 75-88

Saether B-E, Bakke O (2000) Avian life history variation and contribution of demographic traits to the population growth rate. Ecology 81: 642-653 
408 Schalk G, Forbes MR (1997) Male biases in parasitism of mammals: effects of study

409 type, host age, and parasite taxon. Oikos 78: 67-74

410 Schoenle LA, Kernbach M, Haussmann MF, Bonier F, Moore IT (2017) An experimental

411 test of the physiological consequences of avian malaria infection. J Anim Ecol 86: 1483-

$412 \quad 1496$

413 Sehgal RNM (2015) Manifold habitat effects on the prevalence and diversity of avian

414 blood parasites. Int J Parasitol 4: 421-430

415 Sol D, Jovani R, Torres J (2003) Parasite mediated mortality and host immune

416 response explain age-related differences in blood parasitism in birds. Oecologia 135:

$417 \quad 542-547$

418 Tella JL, Blanco G, Forero MG, Gajon A, Donazar JA, Hiraldo, F. (1999) Habitat, world

419 geographic range, and embryonic development of hosts explain the prevalence of

420 avian Hematozoa at small spatial and phylogenetic scales. Proc Natl Acad Sci U.S.A

$42196: 1785-1789$

422 Toyne EP, Ashford RW (1997) Blood parasites of nestling goshawks. J Raptor Res 31:

$423 \quad 81-83$

424 UICN France, MNHN, LPO, SEOF, ONCFS (2016) La Liste rouge des espèces

425 menacées en France - Oiseaux de France métropolitaine.

426 https://inpn.mnhn.fr/docs/LR_FCE/UICN-LR-Oiseaux-diffusion.pdf. Accessed 11

427 March 2020 (in French)

428 Valkiūnas G, Sehgal RNM, lezhova TA, Hull AC (2010) Identification of Leucocytozoon

429 toddi group (Haemosporida: Leucocytozoidae), with remarks on the species

430 taxonomy of leucocytozoids. J Parasitol 96: 170-177

431 Zuur AF, leno EN, Walker N, Saveliev AA, Smith GM (2009) Mixed effects models and

432 extensions in ecology with R. Springer Press, New York 
Fig. 1 Body mass of the 47 Red Kite chicks studied standardised against wing length taken as a proxy of age (Mougeot and Bretagnolle 2006) for females and males separately. The individuals for which DNA from Leucocytozoon ssp. was

437 detected in blood were shown as a black circle in which the corresponding haplotype 1 (L-MILANS4, Genbank accession number JN164713) and/or 2 (LMILVUS1, JN164716) is reported. The grey and black hatched dot corresponds to

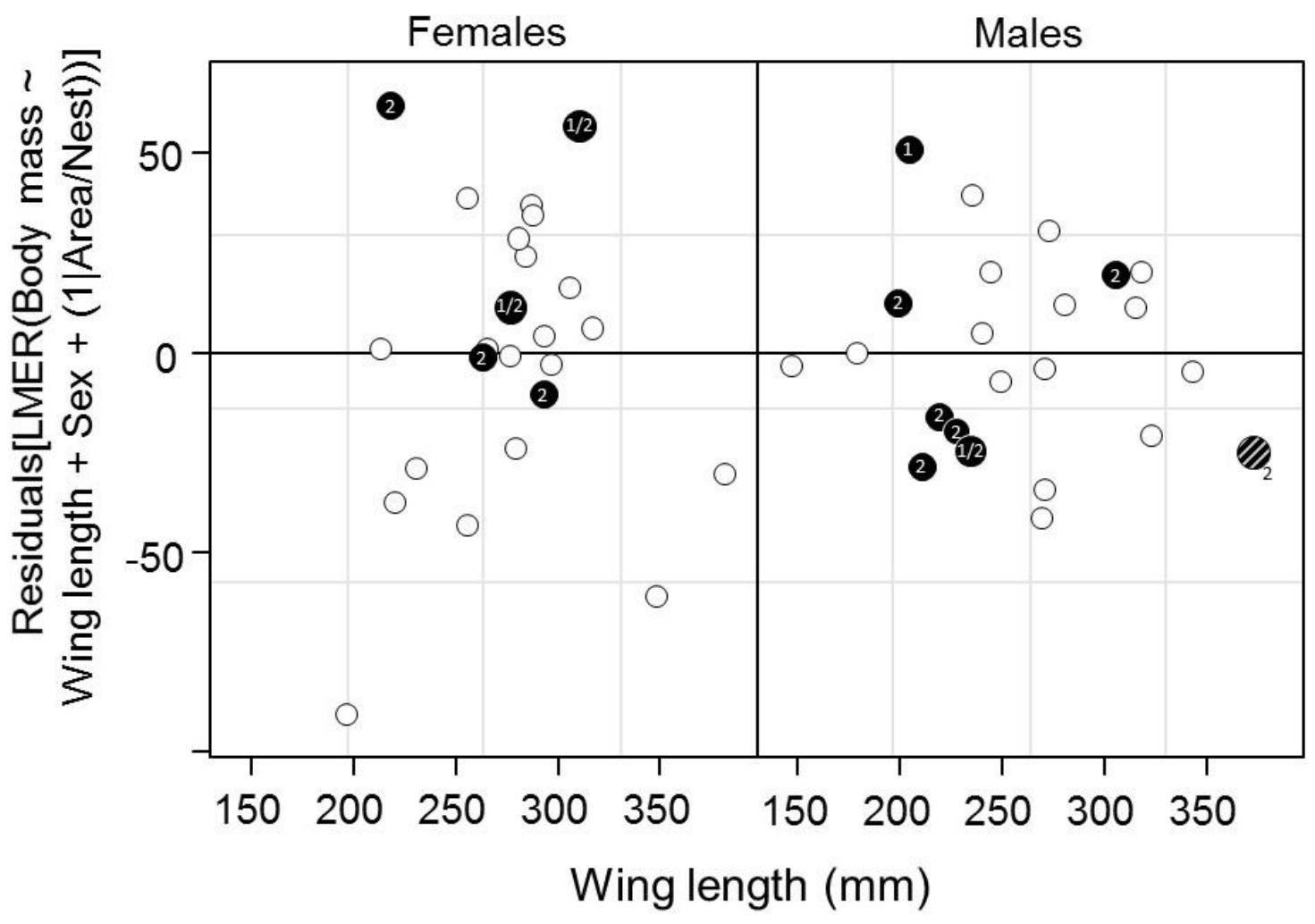


442 Table 1 Linear mixed-effect models tested to explain body mass as response. The best

443 model selected based on corrected Akaike information criteria is reported in bold (LL:

444 maximized log-likelihood; K: number of estimated parameters; AICc: Corrected Akaike's

445 information criterion; w_ic: Akaike weight)

\begin{tabular}{llllll}
\hline Model tested (Body mass ) & LL & K & AICc & $\Delta$ AlCc & w_ic \\
\hline Wing length + Sex + (1|Area/Nest) & $\mathbf{- 2 5 8 . 9}$ & $\mathbf{6}$ & $\mathbf{5 3 2 . 0}$ & $\mathbf{0 . 0 0}$ & $\mathbf{0 . 3 9}$ \\
Wing length + Sex * Status + (1|Area/Nest) & -256.5 & 8 & 532.9 & 0.89 & 0.25 \\
Wing length + Sex + Status + (1|Area/Nest) & -258.1 & 7 & 533.0 & 1.03 & 0.23 \\
Wing length * Sex + (1|Area/Nest) & -258.7 & 7 & 534.2 & 2.20 & 0.13 \\
Wing length + (1|Area/Nest) & -266.1 & 5 & 543.6 & 11.57 & 0.00
\end{tabular}


447 Table 2 Summary of the data available on Red Kite infection by the haemosporidian

448 parasites Leucocytozoon spp. (Leuco.), Haemoproteus spp. (Haemop.) and

449 Plasmodium spp. (Plasmo.). ( $\mathrm{n}=$ total number of screened individuals; $n r=$ not

450 reported; $n s=$ not screened)

\begin{tabular}{lllllll}
\hline Area/country & Age & $\mathrm{n}$ & \multicolumn{2}{c}{ Prevalence in \% [n of infected kites] } & Reference \\
& & & Leuco. & Haemop. & Plasmod. & \\
\hline $\begin{array}{l}\text { Western } \\
\text { Europe }\end{array}$ & $n r$ & 4 & $25[1]$ & $25[1]$ & $0[0]$ & 1 \\
Germany & Nestling & 13 & $15[2]$ & $0[0]$ & $0[0]$ & 2 \\
& Juvenile & 2 & $0[0]$ & $0[0]$ & $0[0]$ & \\
& Adult & 9 & $0[0]$ & $0[0]$ & $0[0]$ & \\
& $n r$ & 2 & $0[0]$ & $0[0]$ & $0[0]$ & 3 \\
UK & $n r$ & 1 & $0[0]$ & $0[0]$ & $0[0]$ & 4 \\
Spain & $n r$ & 46 & $0[0]$ & $0[0]$ & $0[0]$ & 5 \\
& Juvenile & 164 & $4[6]$ & $0[0]$ & $0[0]$ & 6 \\
& Adult & 104 & $2[2]$ & $0[0]$ & $0[0]$ & \\
Denmark & Nestling & 17 & $18[3]$ & $0[0]$ & $0[0]$ & 7 \\
& Juvenile & 1 & $0[0]$ & $0[0]$ & $0[0]$ & \\
& Adult & 1 & $0[0]$ & $0[0]$ & $0[0]$ & \\
France & Nestling & 47 & $28[13]$ & $0[0]$ & $2[1]$ & This study \\
\hline
\end{tabular}

451 1: Peirce (1981), 2: Krone et al. (2001), 3: Krone et al. (2008), 4: Peirce et al. (1983), 5: Tella et al. (1999),

452 6: Pérez-Rodriguez et al. (2013), 7: Laursen (2008). 